\title{
Urban Bias, Economic Resource Allocation and National Development Planning in Botswana
}

\author{
Latang Sechele (Corresponding author) \\ Dept. of Sociology, University of Botswana \\ P/Bag UB00705, Gaborone, Botswana
}

Tel: 267-355-5422Ｅ-mail: sechelelt@mopipi.ub.bw

Received: November 7, 2015 Accepted: December 17, 2015 Published: January 4, 2016

doi:10.5296/ijssr.v4i1.8536 URL: http://dx.doi.org/10.5296/ijssr.v4i1.8536

\begin{abstract}
Michael Lipton formulated a theory of urban bias to account for the poverty and inequalities that rack many developing countries today. The theory proposes that development planning in less developed countries is biased against rural areas in that most of the economic resources are allocated to the urban areas than the rural ones making the poor to get poorer. This article seeks to apply the theory to Botswana's development planning process. Data was obtained from the analysis of the first nine out of the ten national development plans published since independence which clearly show a distinction in economic resource allocations between rural and urban areas. The findings support the urban bias thesis and suggest its retention in studies of economic development with modifications to incorporate elite bias to account for intra-rural and intra-urban social inequalities. It also proposes diversification into non-agricultural activities as a strategy for rural development in drought prone contexts.
\end{abstract}

Keywords: urban bias, resource allocation, development planning, poverty, inequality

\section{Introduction}

With application of modernisation theories after the Second World War up to the 1960s, developing countries were expected to grow economically in order to catch up with western countries. It was thought that industrialisation and economic growth would ultimately lead to a rise in living standards of the majority of people in less developed countries (Todaro, 1989). Studies conducted in the 1970s, however, have shown that economic growth in these countries has not been a problem. Some developing countries have recorded growth rates that have even surpassed those of developed ones. But unlike in western countries, such growth has not at all been able to reduce levels of poverty both in absolute and relative terms 
(Thirlwal, 1978; Todaro, 1989). This has led to the conclusions that economic growth and development therefore, is a process that leads to worsening of living standards. The failure of the development paradigm of the 1950s and 1960s has shifted conception of development to the eradication of social inequalities (Todaro, 1989). Development also in this line entails involving people in decision-making on issues that affect their lives (Chambers, 1983). Lipton (1977) formulated a theory of urban bias which argues that rural areas in less developed countries are facing acute poverty because more resources are allocated to urban development.

Botswana like many developing countries has experienced economic growth, poverty and acute inequalities. As regards Lipton's theory, a review of literature shows that Botswana has been conscious of the consequences of urban bias. Social justice and the need to reduce rural-urban differentials have guided each development plan, beginning with a clear pronouncement in the second development plan. Most importantly, in 1978, a year after the publication of the urban bias thesis, the government of Botswana invited Michael Lipton as a consultant to map up a strategy towards employment creation in Botswana. In view of this consciousness, it is very important to investigate whether this is reflected in the actual allocation of resources. Therefore, this paper attempts to analyse allocation of resources between rural and urban areas, as well as the difference between Botswana government's claims to promote social justice and the effects of its policies. The paper reviews government expenditure between rural and urban development focusing on development plans since independence to the ninth national development plan published in 2003. The paper also briefly explores the implications of urban bias in the development of Botswana's economy.

\section{Urban Bias Theory and Poverty in Developing Countries}

As noted, in the period between the end of the Second World War and 1970, development was perceived largely in economic terms. The root cause of poverty in less developed countries was attributed to factors such as lack entrepreneurial values, use of traditional or less productive technology and lack of economic growth. Western countries were said to have long overcome these hindrances and therefore were models for development (Rostow, 1960). In order for less developed countries to catch up with developed ones, economic growth was viewed as a prerequisite. The goal was to be achieved through industrialisation and even at the expense of agriculture and rural development. It was thought that the benefits of economic growth would trickle down to the mass of the poor (Todaro, 1989).

Studies conducted in the 1970s have revealed that the benefits of economic growth have not been able to reach the majority as envisaged. Growth has been unequally distributed among countries, regions within countries and socio-economic groups (Chenery, 1974). The richest $5 \%$ of income recipients in the less developed world received shares of income that were six times the poorest $20 \%$ (Fields, 1980). The persistence of poverty and inequality despite growth called for a change in the conception of development. Development strategies came to be guided by the objectives of reducing social inequalities in order to maximise distributive justice. Some theories had to be formulated to explain the persistence of poverty and how it could be eradicated. 
One of the concepts that have gained support in development studies today is 'Urban Bias' in development. This rather than the expansion of capitalism or exploitative international relations, which are common with underdevelopment theory, is regarded by many as the explanation of the poverty and inequality that racks so many less developed countries today. This has further been seen as a theory that accounts for the deterioration of living standards in the rural economy. The proponent of such a theory is Michael Lipton (1977). Lipton points out that resource allocation between towns and rural areas shows urban priorities and is therefore not based on equity and efficiency. On the issue of efficiency, Lipton points out that excessive allocation of resources to the urban sector does not lead to high output as could be expected in a given time period (Paine, 1978). He sees the rural sector as having the potential for more growth and that investment in such will be an overriding factor. On the question of equity he points out that a higher proportion of income is distributed to the urban sector than consistent with the maximisation of welfare (Paine, 1978). The concentration of resources in the urban areas helps to improve growth there and produces less growth in the rural economy and at the expense of the rural poor. Lipton (1977) advocates a strategy that will focus on agriculture, which is a dominant means of living for the poor in the less developed world.

Michael Lipton's theory of urban bias is not without support. Robert Chambers (1983) accounts for the persistence of poverty in developing countries and particularly in rural areas. He views poverty, in the same way as Lipton, as extreme in the rural areas, and therefore calling for more emphasis on rural development. He affirms that urban areas get a larger share of human and financial resources than rural areas. Most interesting, Chambers (1983) identifies urban bias in policy formulation, where most of the people who propose solutions to rural poverty are resident in urban areas. On the basis of this it is very unlikely that they have a full understanding of the rural environment and associated problems. Three decades since the formulation of the urban bias thesis and some changes in the price twisting by the World Bank support systems, Bezemer and Heady (2008) found that urban bias continued to persist. This takes the form of less allocation of resources to the rural economy and small holder agriculture in favour of non-farm activities and industrial development in the urban areas. Urban bias is conceived as a great obstacle to growth and poverty reduction in less developed countries. Bezemer and Heady propose that if poverty is to be reduced or eliminated and employment created, this cannot be done when the rural economy and small holder agriculture is neglected. Agriculture especially in the rural economy is regarded as efficient in that it is labour intensive as well as skills intensive such that it generates employment with low entry barriers as compared to other economic activities.

Lipton's theory of urban bias has been attacked. Gugler and Gilbert (1992) point out that the urban / rural explanation of classes is quite simplistic. Lipton points out rural underdevelopment and poverty is a result of excessive allocation of resources to urban development, which is characteristic of all less developed counties. This argument does not get support in situation where allocation of resources has been biased towards rural areas. The authors point out that in India in the 1960s living conditions of the urban poor were bad as compared to their rural counterparts. For instance, between 1960/61 and 1967/68 private consumer expenditure of the bottom $20 \%$ of rural Indians was steady while that of the 
bottom quintile of urban poor deteriorated (page 223). Byres (1978) argues that urban bias theory is narrowly focused since it draws evidence from few Asian countries and poorly represents Africa, Latin America and the Middle East. Furthermore, Lipton fails to examine structural conditions, such as ideological orientation, that result in low urban bias in some countries while in others it is very high. It is held that in socialist countries such as China, there is low urban bias. This might mean that ideology, that is capitalism or socialism, can affect the extent of bias, which Lipton does not explore (Paine, 1978).

Contrary to Lipton's assertion that diversion of resources to the rural sector will improve welfare there, the experiences of many countries in which more resources have been committed to the rural sector, for instance through the 'green revolution', are said to point to the direction of unequal gains. The rich peasants have been able to gain more than the poor landless peasants (Byres 1978). But it has to be noted that the green revolution was a process linked to the notion of economic growth. It appears therefore that there was no targeting for the poor. Lipton advocates a strategy that will focus on small-scale people. Such policies were not pursued at that time. It was a period when the gospel of redistribution was at its infancy stage.

According to Stuart Corbridge (1982), urban bias theory has a dilemma in that it assumes only two class, being the rural class and urban class, and yet there are differential classes within the rural areas too. This is supported by the findings of Griffin and Khan (1978) who give an account and magnitude of the inequalities that occur in less developed countries and in particular Asian countries. They point out that declines in incomes have occurred in rural areas despite agricultural growth. They see the root cause of poverty being the inequalities in the rural areas. Most of the land is seen to be concentrated in the hands of the rich few and development policies geared to their advancement and at the expense of the poor.

On the review of urban bias theory, Griffin (1977) points out that there are differentials that occur in urban areas, where the rich possess more resources than the poor, which the theory does not account for. However, this cannot be taken to dismiss the theory entirely. Griffin and others fail to attack the argument that major decisions on development and the allocation of resources are made by urban based professionals. But it can be argued that urban bias is intertwined with elite bias in the sense that the poor in urban areas suffer but not to an extent that is experienced by the rural poor.

Recent thinking is that we should not treat rural and urban as mutually exclusive sets where there is seemingly no movement of residents between the two domains. Instead, researchers should now explore how the rural and urban are related, how movement between the two could be an advantage to either in terms of improving the livelihoods and contributing to poverty reduction (Jones \& Corbridge, 2010).

It is clear that the theory has little relevance to socialist countries, which might mean that ideologies also affect where resources have to be committed. Although urban bias is relevant to capitalist countries, it may be necessary to find out if it applies to those countries such as Botswana whose development objectives are intended to reduce rural/urban differentials. As noted previously, the critics have attacked the theory for failure to take into account the 
African context. Application of the urban bias theory to Botswana would somewhat serve as a response to some of these critics.

\section{Economic Growth and Poverty in Botswana}

At independence in 1966, Botswana was considered one of the poorest countries in the world with a per capita income of P60, which was equivalent to US\$80. The country relied heavily on beef production to meet the livelihood of its people. Economic reports at that time were invariably gloomy about the potential for future economic development (UNDP/ UNICEF, 1993; Ministry of Finance and Development Planning-MFDP, 2003). However, after the discovery of diamonds, shortly after independence, Botswana rose from being one of the poorest countries in the world to being one of the few African economies that were classified by the World Bank as 'middle income'. Botswana's GDP annual growth rates of $14.3 \%$ from 1966 to 1980 and $12.1 \%$ between 1980 and 1985 were higher than the averages for upper middle-income countries (Owusu, 1997:7). Since independence Botswana has recorded growth rates averaging $9.2 \%$ per annum with per capita income of P9, 359 by year 2002 . Therefore in contrast with many stagnant economies in Africa and the developing world, Botswana became the fastest growing economy (Bank of Botswana, 2002; MFDP, 2003).

Botswana is no exception to other developing countries that have shown rapid growth rates since the 1960s and yet with extremes of poverty and income inequalities. In the early years after independence, the Central Statistics Office conducted two studies to determine the level of poverty that existed at that time. The first one was the rural income survey (1974) and the second was a similar study conducted for urban areas. The findings of the rural income survey were that $45 \%$ of the rural population were living under the poverty datum line with a Gini-coefficient of 0.52, showing highly skewed income distribution (Harvey, 1990: 280). At the same time a survey conducted for urban areas showed that $36 \%$ of households were living under the poverty datum line with a Gini-coeficient of 0.449 , showing a more equitable income distribution (Oommen, 1983:36).

The national household income and expenditure survey, conducted by Central Statistics Office (CSO) revealed that in 1985/86, $59 \%$ of households in Botswana lived under the PDL with the Gini-coefficient of 0.556 reflecting uneven distribution of income nationwide (CSO, 1987). However, the 1993/94 income expenditure survey has shown a decline in the proportion of people living under the PDL from $59 \%$ in $1985 / 86$ to $47 \%$ in 1993/94 (CSO, 1995). Income inequality also decreased slightly from 0.556 to 0.537 respectively (Jefferies, 1996; BIDPA, 1997). By 2013, $18.4 \%$ of the population was living under the PDL with a Gini-coefficient of 0.61 that portrays a relatively unequal distribution of income (African Development Bank, 2014). However, in spite of declines in rates of poverty over the last three decades, Botswana has comparably high levels of poverty in relation to its national per-capita income. Income inequality has increased significantly since independence.

\section{The Significance of National Development Planning}

The government of Botswana has played a major role in the planning process since 1966. Through planning it lays down a roadmap for development policy and economic pursuits. 
Since the government is also involved directly in economic activities, it uses planning to allocate financial resources necessary for the development of urban and rural areas. Planning is supposed to ensure that these resources are used in an efficient and effective manner. As a country that is facing problems of poverty, government expenditure is regarded as important in raising living standards (McCarthy, 1980; MFDP, 1991). Currently the government of Botswana has published ten national development plans and one transitional plan for social and economic development.

Each development plan is guided by five national development objectives of (1) rapid economic growth, (2) social justice, (3) sustained development, (4) economic independence, and (5) economic diversification. These objectives are derived from national principles of democracy, self-reliance, unity and development that are perceived to lead to social cohesion and integrated development (Egner, 1979; MFDP, 1991). Social justice is understood to mean that government creates employment opportunities to enable citizens, especially the very poor, to participate in economic development (see Parsons, 1981). It is supposed to ensure that income differentials between the poor and rich as well as the rural and urban areas are narrowed. Since all the plans recognise that rural development and poverty alleviation are a priority in Botswana, one would expect more financial resources to be allocated to rural areas than urban areas.

\section{Post-Independence Government Development Expenditure Patterns}

This part discusses the allocation of financial resources between rural and urban areas as expressed in the first nine national development plans which show a distinction between these two domains. Since independence, Botswana has experienced high rates of economic growth resulting in the accumulation of substantial amounts of foreign exchange reserves. However, this has largely been out of the sale of minerals and does not reflect engagement in productive activities. The government uses proceeds from the sale of these commodities to develop both urban and rural areas.

\subsection{National Development Plan I}

Table 1 shows the allocation of government resources in the first national development plan. At the time of independence and until 1976, Botswana was using the South African Rand. This table is indicative of the priorities of the government for development at the time of independence. There is a disproportionate allocation of government spending in favour of urban development, and very few resources are committed to the rural sector and particularly agriculture. Out of a total of R63.5 million, over R55.1 million or $85 \%$ of development funds were allocated for urban related activities. The greatest priorities were the development of social and physical infrastructure. 
Table 1. Summary of proposed development expenditure 1968-73 (National development plan I)

\begin{tabular}{lc}
\hline Type of expenditure & Amount of allocation- Rand (million) \\
\hline Total development expenditure allocated to: & 63.5 \\
Agriculture-rural water development & 0.8 \\
Urban industrial development & 52.1 \\
Urban water development & 2.1 \\
Urban health development & 0.9 \\
Rural health development & 0.5 \\
Capital for National development Bank allocated to: & \\
Rural water and agricultural credit & 1.0 \\
Commercial and industrial credit & 1.2 \\
Credit for housing & 2.9 \\
\hline
\end{tabular}

Source: Jackson (1970).

Pre-independence reports conducted on the economy of Botswana had recommended that the government starts off with agricultural development as a strategy for growth and raising of income for the people of Botswana and that industrial development is left to private sector initiatives (Jackson, 1970; Jones 1977; McCarthy, 1980). This strategy was, however, abandoned following the discovery of minerals; mining industry and urban development were adopted as the best strategy for rapid economic growth. Urban areas were also perceived to be having the potential for growth and development that would benefit all regions including rural areas. It was therefore imperative that the government spent much of its resources on the development of infrastructure in towns, entailing provision of roads, telephone systems and the building of schools and other facilities that were associated with urban life (Picard, 1987).

\subsection{National Development Plan II}

The neglect of the rural economy later became a political problem and led to the unpopularity of the ruling Botswana Democratic Party in some rural areas. In the 1969 elections for instance, the ruling party lost all the parliamentary seats, which were in their hands in the Ngwaketse areas in the Southern District (McCarthy, 1980). Following this loss, the government began to think seriously about how to develop the rural economy and to redress urban bias. In the second national development plan 1970-1975, the government undertook to promote an equitable distribution of income by reducing income differentials between the urban and rural sectors through rural development. To demonstrate its commitment to the policy of rural development, the government formulated its first basic rural development policy in 1973 whose major aims were to: (1) increase sustained production from land and wildlife through research, co-ordinated extension works, conservation and land use planning, (2) improve marketing and credit facilities in rural areas and (3) create new employment opportunities wherever feasible and thereby reduce the number of people without any means of support (Bhuiyan, 1987). This policy guided rural development initiatives for 30 years until it was revised in 2002 to keep pace with social change (Ministry of Finance and 
Development Planning, 2002:13).

During this period two development programmes, the Accelerated Rural Development Programme (ARDP) and Tribal Grazing Land Policy (T.G.L.P), were formed as part of the package for rural development. The T.G.LP was formed in 1975 in order to alter the traditional forms of land tenure for cattle farmers so that improved conservation and production methods could be applied and farmers could be given incentives to preserve the productive capacity of the land. However, the fact that it focused on large scale farmers meant that it benefitted the rich at the expense of the poor farmers. According to Reynolds (1977), half of the cattle sold at the Botswana Meat Commission abattoir in 1977 came from the newly established T.G.L.P ranches which contained only $4 \%$ of the population. Furthermore, the Basarwa (San) were displaced without compensation from their land to give way for the establishment of ranches. The programme had the effect of exacerbating inequalities in the rural areas (Sechele, 1996). The ARDP, formulated in 1973, emphasised the construction of physical and social infrastructure such as roads, schools and clinics in rural areas. The programme, which operated between 1973 and 1976, was successful in winning back the seats the ruling party had lost during the 1969 elections (Jones, 1977). But generally it did very little to address the urban bias question.

\subsection{National Development Plan III}

Urban bias continued to be evident in the third national development plan. As Table 2 clearly shows, despite the government's claim to support rural development and notably physical and social infrastructure, commitment to rural development was far less than that for urban development between the end of the second development plan and the beginning of the third development plan period. For example, $47 \%$ or close to half of the Ministry of Local Government and Lands development funds for 1975 and 1976 were spent exclusively on urban infrastructure and $35 \%$ on primary school equipment. The remaining $18 \%$ was spent on rural infrastructure $(17 \%)$ and other development needs $(1 \%)$. It is however, not clear whether primary school equipment and 'other' categories were urban or rural. But looking at physical infrastructure expenditure patterns for the period it is most likely that far more was spent in urban areas than rural areas.

Table 2. Breakdown of development spending of the Ministry of Local Government and Lands between 1975 and 1976

\begin{tabular}{llc}
\hline Type of expenditure & Amount -Pula (million) & Percentage \\
\hline Infrastructure in towns & 4.9 & 47 \\
Rural infrastructure & 1.8 & 17 \\
Primary school equipment & 3.7 & 35 \\
Other & 0.1 & 1 \\
Total & 10.5 & 100 \\
\hline
\end{tabular}

Source: Charles Harvey (1990). 


\subsection{National Development Plan IV}

This pattern of expenditure was to be repeated in the fourth national development plan covering the period 1976 to 1981 . As Table 3 shows, there is much of activity that is associated with development of infrastructure. Most of the funds planned for the period were absorbed by construction of roads and urban development, constituting $47.6 \%$ of development funds. It has to be noted also that most of the main roads that are recorded as 'main' are those linking major towns and a few main villages. The funds allocated to Agriculture, Tribal Grazing Land Policy, Major and Rural Village Water Supply, and Rural Development line items, that are exclusively rural in nature, make only $14.5 \%$ of the development expenditure. This is far below an exclusively Urban Development line item that makes up $23.4 \%$ of total expenditure. Apart from the fact that expenditure for this period is biased in favour of urban development, there is very little allocated to productive activities that could raise living standards.

Table 3. Domestic development expenditure for national development plan IV

\begin{tabular}{lc}
\hline Category of expenditure & Percentage of total \\
\hline Main roads and Development & 24.2 \\
Urban Development & 23.4 \\
Primary and secondary schools & 11.1 \\
Major and rural village supply & 2.7 \\
Agriculture & 4.0 \\
Tribal Grazing Policy related & 6.2 \\
Health & 2.1 \\
Rural roads & - \\
Rural Development & 2.6 \\
Administrative infrastructure & 12.3 \\
Botswana Enter Prise Development & 1.1 \\
Industrial Building leasing & \\
Trade and extension & 10.3 \\
Other & 100 \\
\hline Total expenditure & \\
\hline
\end{tabular}

Source: Parson J (1981).

In 1977, which is within the national development plan IV period, the economy of Botswana was plagued with problems of employment and underemployment, which were compounded by the loss of jobs by citizens of Botswana who worked in South Africa. For instance about $50 \%$ were losing jobs every year (Mayende, 1990). Also the rate of formal employment in the mines and particularly urban areas was not enough to absorb the majority of labourers from the rural areas. It was at this stage that the government of Botswana began to seek ways 
of creating jobs for the benefit of Batswana (people of Botswana). The government invited Michael Lipton to study employment problems and make suggestions as to how such problems could be alleviated. Michael Lipton (1978) condemned the nature of expenditure that was being pursued at that time. He described it as wasteful in that it concentrated on the provision of infrastructure and mostly urban oriented and paid little attention to productive activities. Lipton advocated a strategy that would focus production on small business people. He was very vocal on the need to develop agriculture, which he thought was the best way to address the question of urban bias.

\subsection{National Development Plan V}

National development plan $\mathrm{V}$ took cognisance of the problems raised within the Lipton report and accepted the proposal to reorient development towards productive activities. This period saw the formulation of three policies in this line. In agriculture there was the formulation of Arable Land Development Policy in 1978/1979 and the Accelerated Rain-fed Arable Programme in 1985 (Picard, 1987; Solway, 1994). These programmes were intended to encourage arable production and reduce urban drift. The Financial Assistance Policy (FAP) was formulated in 1982 to encourage both large and small scale manufacturing activities. Its objectives entailed (a) job creation, (b) diversification and growth of the economy and (c) encouragement of Batswana (Botswana citizens) to participate in development (Phaleng, 1995). Here the government offered financial grants to individuals and companies seeking to venture into manufacturing enterprises. Quite importantly, those companies and individuals who sought to start businesses in the rural areas were to be given larger shares of financial grants. But urban areas also enjoy tax-free incentives, which are not accorded to those locating in the rural areas (MFDP, 1991). The formulation of such policies would suggest that more resources were to be allocated to productive activities and more importantly to rural development. But as Table 4 indicates, there is a lot of bias on infrastructure and urban related activities as was the case since independence.

The development of the Gaborone airport, northern abattoir, and Jwaneng equity, which are activities that are located in urban areas, constitute $18.3 \%$ of the development expenditure. Comparably, Cattle Related, Agriculture, and Arable Land Development, which are rural, make up only $14.9 \%$ of the development expenditure for the period. Although the amount of funds in terms of percentage allocated to the rural areas is still too little there is evidence of an increase in overall expenditure on rural development as compared to expenditures in the previous periods. In spite of the emphasis on productive activities, only $1.3 \%$ of funds were allocated to industry and other commercial activities. But generally one can conclude that the highest priority was accorded to the urban sector than on productive activities and rural development. It is worth noting that while the arable agricultural programmes were meant to reduce poverty, the rich benefitted more from government subsidies that were tied to these programmes than the poor who participated less. The rich and middle income had resources in the form of cattle and tractors that enabled them to plough huge chunks of land while the poor lacked these resources (Sechele, 1996). 
Table 4. Domestic development expenditure for national development plan 1979-85

\begin{tabular}{lc}
\hline Category & Percentage of total \\
\hline Administrative infrastructure & 11.9 \\
Main rail way take over & 10.6 \\
Primary and secondary schools & 9.6 \\
Main and secondary roads & 8.7 \\
Urban Development & 8.3 \\
Botswana Defence Force & 7.5 \\
Cattle related & 4.4 \\
New Gaborone airport & 4.2 \\
Jwaneng Equity & 3.5 \\
Rural Development & 4.4 \\
Northern abattoir & 2.3 \\
Other Agriculture & 2.3 \\
Major village development & 1.9 \\
Arable Lands Development & 1.9 \\
Health & 1.5 \\
Industry, Manufacturing and commerce & 1.3 \\
Other & 15.7 \\
Total Expenditure & 100 \\
\hline
\end{tabular}

Source: National development plan five in Jack Parson (1984).

\subsection{National Development Plans VI, VII, VIII and IX}

The national development plans six, seven, eight and nine do not clearly categorise and summarise development expenditure in terms of what is urban and rural. It also is not clear to distinguish between funds allocated to what is productive activity and what they are not. However, analysis of some ministerial planned development expenditures where there is a distinction between rural and urban expenditure would hint the path which the planning process follow in these plans. It has to be noted that the sixth, seventh, eighth and ninth national development plans have emphases on productive activities and their tone is to diversify the economy through introduction of these activities. The sixth national development plan clearly emphasises rural development, employment creation through improvement in commerce and industry and greater encouragement of small scale arable production (Bhuiyan, 1987). Indeed evidence has shown that the plan sought to fulfil some of its objectives. In this plan for instance, for the first time in the history of Botswana arable agriculture, which is the primary economic occupation of the majority of Batswana, was allocated funds which exceeded those allocated for livestock development (Harvey, 1990; MFDP, 1991). The development expenditure for the Ministry of Local Government, Lands and Housing in the sixth national development plan shows that urban areas were allocated P180 million while rural areas were allocated about P200 million (MFDP, 1991). The plan 
shows that slightly more resources were allocated to the rural areas. This has also been for the first time in the history of independent Botswana for any allocation classified as urban to be exceeded by what is classified as rural. Table 5 shows the planned allocation of resources between urban and rural development for the Ministry of Local Government Lands and Housing.

Table 5. Ministry of Local Government development expenditure, 1991/92 - 1996/97 (Seventh national development plan)

\begin{tabular}{llllllrl}
\hline & $1991 / 92$ & $1992 / 93$ & $1993 / 94$ & $1994 / 95$ & $1995 / 96$ & $1996 / 97$ & TOTAL \\
\hline Rural & 95.08 & 96.92 & 92.30 & 92.10 & 91.60 & 91.60 & 559.60 \\
Urban & 228.62 & 228.33 & 49.50 & 27.10 & 12.50 & 4.25 & 550.30 \\
Other & 25.79 & 28.51 & 30.50 & 30.30 & 29.30 & 28.80 & 173.20 \\
Total & 349.49 & 353.76 & 172.30 & 149.50 & 133.40 & 124.65 & 128.10 \\
\hline
\end{tabular}

Source: National development plan seven (MFDP, 1991).

A disproportionate allocation of resources is in favour of urban development in the financial years of 1991/92 and 1992/93. The major explanation for urban bias here is the formulation of the Accelerated Land Servicing Programme (ALSP) by the government to expedite provision of serviced industrial and residential land in urban areas. The provision of land was thought to be necessary for commercialisation and establishment of industries in urban areas (Toteng, 1995). Total expenditure that was planned for the Ministry of Local Government and Lands in the seventh national development plan was slightly in favour of rural areas, which is a departure from urban bias that was predominant over most of the post-independence period.

Other Ministries have indicated a near balance between urban and rural resource allocations even though slightly in favour of urban centres. For instance, in the seventh national development plan, out of P703.9 million development expenditure for the Ministry of Water Affairs (Table 6), a total of P343.1 million (49\%) was allocated to Urban centres as compared to P262.2 million (37\%) allocated to rural areas constituted by Main Villages and Lands areas line items. The remaining P81.3 million (14\%) was allocated to Research and Development as well as other unspecified items.

In the National development plan eight, even though it is not clear as to the allocation of funds according to rural-urban categories, there is some evidence that the government is becoming more sensitive to the development of rural areas than it had been for most of the post-independence period. For example, out of the P153, 70 million planned for the country's energy sector, P135, 00 million (89\%) is targeted for rural power supplies (MFDP, 1998:225). Further to this, the plan emphasises development of rural areas with the ultimate objective of modernising them into urban areas as well as reducing dependency on agriculture, which is vulnerable to droughts, as a source of livelihood. National development plan nine emphasises strategic planning with a focus on the implementation of the plan as well as its objectives as documented. The policy thrust here entails, among others, economic diversification, rural 
development, and poverty alleviation as a strategy for development.

It would be too simplistic to argue on the basis of these statistics, that urban bias has been completely eliminated in Botswana. Considering that close to half of the population of Batswana lived in rural areas by the end of the ninth national development plan and that the rural areas have suffered neglect since independence, there should have been a disproportionate expenditure in favour of rural areas. A near balance or equal expenditure will do very little to reduce rural-urban differentials.

Table 6. Planned development expenditure (Ministry of Water Affairs) 1991-97

\begin{tabular}{lc}
\hline & Amount in Pula (million) \\
\hline Urban centres & 343.1 \\
Main villages & 215.1 \\
Lands areas & 47.1 \\
Research and Development & 19.5 \\
Other & 61.8 \\
Total & 703.9 \\
\hline
\end{tabular}

Source: National development plan seven (MFDP, 1991).

\section{Social Implications of Urban Bias}

It is quite evident that government allocation of resources for much of the period after independence has been biased against rural development. As a result of this nature of allocation, living conditions in the urban areas have consistently improved while those in rural areas have generally shown signs of deterioration. In 1974 about $45 \%$ of the rural population were living under the PDL and this rose to $64 \%$ in the $1980 \mathrm{~s}$. At the same time urban absolute poverty decreased from $36 \%$ in the 1970 s to $30 \%$ in $1985 / 1986$ (CSO, 1987; CSO, 1991a). By late 1990s, $55 \%$ of remote rural dwellers lived under the PDL as compared to only $28 \%$ in designated towns (BIDPA, 1997).

Table 7 shows vast differences in average incomes between urban and rural households. The male headed-household in urban areas has an income which almost doubles that of the rural household. The urban female-headed household earns income which is more than double that of female-headed household in the rural areas. The table generally indicates that males have more income than females. It further shows that there is a general problem of income distribution that applies to both urban and rural areas. However, in relative terms urban areas are better off than rural areas. 
Table 7. Average household income distribution in Botswana (in Pula)

\begin{tabular}{lllll}
\hline Area & Male headed & Female headed & Male & Female \\
\hline Urban & 499.02 & 253.60 & 399.06 & 260.76 \\
Rural & 259.58 & 102.93 & 118.50 & 101.40 \\
\hline
\end{tabular}

Source: Odetei (1995).

As in many less developed countries where urban bias is predominant, there has been a significant increase in urban population growth rates in Botswana in the last four decades. The proportion of the urban population rose from $9 \%$ in 1971 to $18 \%$ in $1981,46 \%$ in 1991 , $54 \%$ in 2001 and $64 \%$ in 2011. Comparably the rural population has declined from $91 \%$ in 1971 to $54 \%$ in 1991, $46 \%$ in 2001 and $36 \%$ in 2014 (CSO, 1991b; CSO, 2001; MFDP2003; Statistics Botswana, 2014).

\section{Conclusion}

While there have been scathing attacks on the urban bias thesis by some scholars, an analysis of Botswana's economic development plans since independence demonstrates that the concept is still valid and relevant in understanding development processes in Developing countries today. An appreciation of existing disparities between the rural and urban domains would do more to motivate development practitioners and governments to formulate policies and strategies towards realising more equitable developments. These should inform how development funds should be distributed nationally. Failure to take note of these long standing disparities will result in an ever widening gap between the two centres with implications that the rural areas will continue to trail behind in as far as development is concerned. Although proponents of the urban bias thesis give more attention to the agricultural sector as a way of boosting the rural economy, it is crucial to also explore alternative livelihood activities, such as tourism, in drought prone economies such as Botswana. Attention must also be paid to developing poverty reduction strategies that would reduce intra-rural disparities by targeting the very poorest members of the community.

\section{References}

African Development Bank. (2014). Botswana: Economic outlook. Retrieved April 8, 2015, from http://www.afdb.org/en/countries/Southern-africa/botswana/botswana-economicoutlook

Bank of Botswana. (2002). Annual report 2002. Gaborone: Bank of Botswana.

Bezermer, D., \& Heady, D. (2008). Agriculture, development and urban bias. World Development, 36(8), 1342-64. http://dx.doi.org/10.1016/j.worlddev.2007.07.001

Bhuiyan, M. (1987). Selected papers on the economy of Botswana. Gaborone :Bank of Botswana.

Botswana Institute of Development Policy Analysis. (1997). Study of poverty and poverty alleviation in Botswana, Volume 1. Gaborone: Ministry of Finance and Development Planning, 
Byres, T. J. (1978). Of neo-populist pipe-dreams: Daedalus in the Third World and the myth of urban bias. Journal of Peasant Studies, 6, 210-44. http://dx.doi.org/10.1080/03066157908438073

Central Statistics Office, CSO. (1987). 1985/86 household income and expenditure survey. Gaborone: Ministry of Finance and Development Planning.

Central Statistics Office, CSO. (1991a). A poverty datum line for 1989. Gaborone: Ministry of Finance and Development Planning.

Central Statistics Office, CSO. (1991b). Population and housing census. Gaborone: Ministry of Finance and Development Planning.

Central Statistics Office, CSO. (1995). 1993/94 household income and expenditure survey. Gaborone: Ministry of Finance and Development Planning.

Central Statistics Office, CSO. (2001). Population and housing census. Gaborone Ministry of Finance and Development Planning.

Chambers, R. (1983). Rural development: Putting the last first. New York: Longman.

Chenery, H. (1974). Introduction. In H. Chenery, R. Jolly, M. S. Ahluwalia, C. L. Bell \& J. H. Duloy (Eds.). Redistribution with growth: Policies to improve income distribution in developing countries in the context of economic growth. World Bank research series. New York: World Bank, Oxford University Press.

Egner, E. (1979). Review of socio- economic development in Botswana. Gaborone: CIDA.

Fields, G. (1980). Poverty, inequality, and development. London, Cambridge University Press. http://dx.doi.org/10.1017/cbo9780511572173

Gilbert, A., \& Josef, G. (1992). Cities, poverty and development: Urbanisation in the Third World (3rd ed.). Oxford: Oxford University Press.

Griffin, K. (1977). Review of Lipton's why poor people stay poor. Journal of Development Studies, 14(1), 108-9. http://dx.doi.org/10.1080/00220387708421665

Griffin, K., \& Khan, A. (1978). Poverty in the Third World: Ugly facts and fancy models. World Development, 6(3), 295-304. http://dx.doi.org/10.1016/0305-750X(78)90109-2

Harvey, C., \& Lewis, S. R. (1990). Policy choice and development performance in Botswana. London: Macmillan.

Jackson, D. (1970). Income differentials and unbalanced planning: The case of Botswana. Journal of Modern African Studies, 8(4), 553-62. http://dx.doi.org/10.1017/S0022278X00023892

Jefferies, K. (1996). Poverty in Botswana. Gaborone: Botswana Society.

Jones, D. (1977). Aid and development in Southern Africa: British Aid to Botswana, Lesotho and Swaziland. London: Croom Helm. 
Joes, G., \& Corbridge, S. (2010). The Continuing debate about urban bias: Thesis, its critics, its influence and its implications for poverty reduction strategies. Progress in Development Studies, 10(1), 1-18. http://dx.doi.org/10.1177/146499340901000101

Lipton, M. (1977). Why poor people stay poor: A study of Urban Bias in World Development. Temple Smith/Harvard University Press.

Lipton, M. (1978). Botswana: Employment and labour use in Botswana final report: Vol. 1. Gaborone: Government Printer.

Mayende, P. (1990). Rural development policy and women: The case of ALDEP in Botswana. Hull: University of Hull.

McCarthy, S. \& Colclough, C. (1980). The political economy of Botswana: The study of growth and distribution. Oxford University Press, Oxford.

Ministry of Finance and Development Planning-MFDP. (1991). National development plan 7:1991-1997. Gaborone: Government Printer.

Ministry of Finance and Development Planning-MFDP. (1997). National development plan 8: 1998-2003. Gaborone: Government Printer.

Ministry of Finance and Development Planning-MFDP. (2002). Revised national policy for rural development. Gaborone: Government Printer.

Ministry of Finance and Development Planning-MFDP. (2003). National development plan 9:2003-2008. Gaborone: Government Printer.

Odotei, E. (1995). Rural-urban relationships: Report of the national rural development workshop, 20-24 March (pp. 188-197). Gaborone: Ministry of Finance and Development Planning.

Oommen, M. A. (1983). Growth with equity: Some explanatory hypotheses based on the structure and pattern of distribution. In M. A. Oommen, T. K. Inganji, \& L. D. Ngcongco (Eds.). Botswana economy since independence (pp. 29-55). New Delhi: Tata McGraw-Hill.

Owusu, F., \& Samatar, A. (1997). Industrial strategy and the African state: The Botswana experience. University of Minnesota, Minnesota. http://dx.doi.org/10.2307/486181

Paine, S. (1978). Some reflections on the presence of 'rural' or 'urban' bias in China's development policies 1949-76. World Development, 6, 693-707. http://dx.doi.org/10.1016/0305-750X(78)90085-2

Parsons, J. (1981). Cattle, class and the rural state in Botswana. Journal of Southern African Studies, 7(2), 236-55. http://dx.doi.org/10.1080/03057078108708027

Parson, J. (1984). Botswana: Liberal democracy and the labour reserve in Southern Africa. London: Westview Press.

Phaleng Consultancies. (1995). Third evaluation of the Financial Assistance Policy: Final Report. Gaborone: Government Printer. 


\section{Macrothink}

International Journal of Social Science Research

ISSN 2327-5510 2016, Vol. 4, No. 1

Picard, L. (1987). The Politics of development in Botswana: A model for success? London: Lynne Rienner Publishers.

Rostow, W. (1960). The stages of economic growth: A non-communist manifesto. Cambridge: Cambridge University Press.

Solway, J. (1994). Drought as a "revelatory crisis": An exploration of shifting entitlements and hierarchies in the Kalahari, Botswana. Development and Change, 25(3), 471-495. http://dx.doi.org/10.1111/j.1467-7660.1994.tb00523.x

Sechele, L. T. (1996). Urban bias, social justice and rural development in Botswana. MA thesis, University of Essex.

Statistics Botswana. (2014). Population and housing census 2011: Analytical report. Gaborone: Statistics Botswana.

Thirlwal, A. (1978). Growth and development with special reference to developing countries. London: Macmillan.

Todaro, M. (1989). Economic development in the Third World. 4th edn. London: Longman.

Toteng, N. (1995). Urbanisation, population growth and informal settlements in Botswana. Gaborone: Applied Research Unit.

UNDP/UNICEF. (1993). Planning for people: A strategy for accelerated human development in Botswana. Gaborone: Ministry of Finance and Development Planning.

\section{Copyright Disclaimer}

Copyright for this article is retained by the author(s), with first publication rights granted to the journal.

This is an open-access article distributed under the terms and conditions of the Creative Commons Attribution license (http://creativecommons.org/licenses/by/3.0/). 